\title{
Removal of sulfur contaminants from biogas to enable direct catalytic methanation
}

\author{
Christian Dannesboe ${ }^{1}$ (I) $\cdot$ John Bøgild Hansen ${ }^{2} \cdot$ Ib Johannsen ${ }^{1}$
}

Received: 4 September 2019 / Revised: 22 November 2019 / Accepted: 3 December 2019 / Published online: 18 December 2019

(C) The Author(s) 2019

\begin{abstract}
In the near future, renewable energy sources will replace fossil energy. To allow full carbon utilization of renewable biomass, we have demonstrated a possible integration between a biogas reactor, an electrolysis unit, and a catalytic methanation reactor. Stringent removal of all sulfur contaminants in raw biogas is required to enable this integration. We demonstrate how existing bulk sulfur removal solutions, like a biotrickling filter loaded with Acidithiobacillus thiooxidans and impregnated activated carbon, are unable to meet this requirement. Only the main sulfur contaminant hydrogen sulfide $\left(\mathrm{H}_{2} \mathrm{~S}\right)$ can effectively be removed. Contaminants carbon disulfide $\left(\mathrm{CS}_{2}\right)$, dimethyl sulfide (DMS), and carbonyl sulfide (COS) will leak through the carbon filter, long before hydrogen sulfide can be detected. Utilization of surplus oxygen from the combined system is proven problem free and allows sulfur removal without introducing contaminants. Provided that a recommended sulfur guard is included, the proposed design is ready for full-scale implementation.
\end{abstract}

Keywords Biotrickling filter $\cdot$ Carbon filter $\cdot$ Biogas methanation $\cdot$ Biogas contaminants $\cdot$ Power to methane

\section{Introduction}

Production of energy from biomass is one of the technologies enabling a fossil-free future. In Northern Europe, biogas facilities are widespread [1], and many of the plants built just 10 years ago are extending their processing capability [2].

\section{Highlights}

- Pure oxygen available from the electrolysis of the combined power-tomethane system removes nitrogen contamination.

- $\mathrm{H}_{2} \mathrm{~S}$ is efficiently removed using impregnated activated carbon; however DMS and $\mathrm{CS}_{2}$ leak through.

- The proposed treatment removes biogas contaminants to a level enabling direct methanation.

Christian Dannesboe

chda@eng.au.dk

John Bøgild Hansen

jbh@topsoe.com

Ib Johannsen

ibj@eng.au.dk

1 Department of Engineering, Aarhus University, Hangoevej 2, DK-8200 Aarhus N, Denmark

2 Haldor Topsøe A/S, Nymøllevej 55, DK-2800 Kongens Lyngby, Denmark
Production of biogas is used as an efficient way to handle waste streams from agricultural production facilities, and biogas reactors at wastewater treatment plants are being installed to reduce the overall energy requirement. The produced biogas is carbon neutral, and the main component in the biogas, methane $(\sim 55-70 \%)$, is easily moved from producer to consumer/storage via the existing natural gas grid. Export of methane to the grid will require the main byproduct in biogas, $\mathrm{CO}_{2}(\sim 30-45 \%)$, to be removed on-site [3]. Several proven separation systems are available like amine or water scrubbers as well as pressure swing adsorption. The success of biogas is not without limitations. Available biomass is a restricted resource, and replacing natural gas in this way will not be possible. Currently gas consumption is at a high level in multiple sectors: industrial, district heating, and transport [4].

A way to provide a substantial boost to biogas plant methane output is to include a methanation reactor in the plant design, enabling conversion of the by-product $\mathrm{CO}_{2}$ to more methane via the Sabatier reaction [5] (Eq. 1).

$\mathrm{CO}_{2(\mathrm{~g})}+4 \mathrm{H}_{2(\mathrm{~g})} \rightleftarrows \mathrm{CH}_{4}(\mathrm{~g})+2 \mathrm{H}_{2} \mathrm{O}_{(\mathrm{g})} \Delta \mathrm{H}_{300^{\circ} \mathrm{C}}=-165 \frac{\mathrm{kJ}}{\mathrm{mol}}$

Catalytic methanation of carbon monoxide (CO) is often considered along with the Sabatier reaction, and this reaction 
will release even more energy (Eq. 2). The content of CO in biogas is however very low and primarily found in gas from landfills [6].

$$
\mathrm{CO}_{(\mathrm{g})}+3 \mathrm{H}_{2(\mathrm{~g})} \rightleftarrows \mathrm{CH}_{4}(\mathrm{~g})+\mathrm{H}_{2} \mathrm{O}_{(\mathrm{g})} \quad \Delta \mathrm{H}_{300^{\circ} \mathrm{C}}=-206 \frac{\mathrm{kJ}}{\mathrm{mol}}
$$

Catalytic methanation technology has been proven for decades on syngas from various sources [7]. This enables production of synthetic natural gas using $\mathrm{H}_{2}$ and a mixture of $\mathrm{CO}$ and $\mathrm{CO}_{2}$. Using a biogas feed without $\mathrm{CO}$ for the catalytic methanation results in a reduced adiabatic temperature and reduces the risk of carbon formation in the reactor $[8,9]$. From a safety perspective, it is also easier to manage plant maintenance activities when the very toxic $\mathrm{CO}$ is not present. The mechanism of catalytic $\mathrm{CO}_{2}$ methanation is still being discussed [10], as results from different groups point towards two different pathways. Results from Eckle et al., Karelovic and Ruiz, as well as Akamaru et al. point towards a $\mathrm{CO}$ intermediate based on catalyst containing $\mathrm{Ru}$ or $\mathrm{Rh}$ [11-13]. However, the findings of Aldana et al., Pan et al., as well as Park and McFarland [14-16] indicate $\mathrm{CO}_{2}$ adsorption to the catalyst support and subsequent hydrogenation to methane. These last studies are done with $\mathrm{Ni}$ or Pd catalyst and propose formate or carbonate as the intermediate but also highlight the importance of the support material. Methanation plants operating on pure $\mathrm{CO}_{2}$ sources have been in operation for years [17], whereas direct $\mathrm{CO}_{2}$ methanation in biogas is a rather new idea with pilot plant activities booming since 2013 [18].

Continued development of electrolyzer technologies, like alkaline, proton exchange membrane, and solid oxide electrolysis cells (SOEC), has enabled a cheap and fossil-free hydrogen production from photovoltaics and wind farms [19]. Specifically SOEC-based electrolyzers are able to utilize several synergies when combined into electrolyzer-methanation units, enabling methanation of $\mathrm{CO}_{2}$ directly in biogas [20]. The first results from such combined pilot facilities are now becoming available (2019), showing potential for a very high plant efficiency $[9,21]$. Full integration between biogas production, electrolysis, and catalytic methanation will boost the methane output by $40-80 \%$ and ensure full utilization of carbon from biomass. The individual technologies are already available at an industrial scale, indicating that a single, cheap, full-scale solution for direct upgrading of biogas is soon to become available.

The focus of this paper is the challenge of deep sulfur removal at biogas sites using proven sulfur treatment solutions like a biotrickling filter and/or impregnated activated carbon. Deep sulfur removal will be required to enable direct catalytic methanation of biogas, as sulfur contamination, even in the range of $1-10 \mathrm{ppb}_{\mathrm{V}}$, is known to cause problems [22]. The potential benefits of utilizing the surplus oxygen stream from the integrated electrolyzer-methanation unit are evaluated.

\subsection{Technical aspects of biogas treatment}

The main concerns with regard to export of methane from biogas facilities are high levels of $\mathrm{CO}_{2}$ and hydrogen sulfide $\left(\mathrm{H}_{2} \mathrm{~S}\right)$ as well as a high moisture level [1, 2, 23, 24]. A simple gas dryer easily reduces the specified requirements on dew point to acceptable levels, but $\mathrm{CO}_{2}$ and $\mathrm{H}_{2} \mathrm{~S}$ are more complicated to remove.

\subsubsection{Removal of $\mathrm{CO}_{2}$}

The removal of $\mathrm{CO}_{2}$ can be performed by several technologies like membranes, pressure swing adsorption (PSA), or chemical scrubbers. Chemical scrubbers use solvents like methyldiethanolamine (MDEA), polyethylene glycol mixtures, or water. According to Sheets and Shah [25], this last type of $\mathrm{CO}_{2}$-scrubber using pressurized water is the most common biogas cleaning method (used at $\sim 40 \%$ of all projects worldwide). Comparison of different $\mathrm{CO}_{2}$ removal technologies as well as current operational costs can be found in the review by Bauer et al. [1]. This review covers $\mathrm{CO}_{2}$ removal technologies used in Northern Europe (Sweden, Germany, the Netherlands, UK, and Denmark). Even the earliest commercial technologies like pressurized water scrubbing (Fig. 1) and PSA have a low methane slip and will recover more than $97 \%$ of the methane [1].

Updated designs are showing further improvements, and a new technology like the MDEA scrubber is delivered with a guarantee of $99.9 \%$ methane recovery [26]. In newer unit designs, $\mathrm{H}_{2} \mathrm{~S}$ is always removed before the $\mathrm{CO}_{2}$ separation step to reduce risk of corrosion and to ensure subsequent release of $\mathrm{CO}_{2}$ to the atmosphere does not cause health or smell concerns. Although a stream rich in $\mathrm{CO}_{2}$ is made available by the removal process, recovery and reuse are yet to become the norm. The $\mathrm{CO}_{2}$ is typically diluted with strip air and contains the contaminants $\mathrm{CH}_{4}, \mathrm{H}_{2} \mathrm{O}$, as well as trace amounts of $\mathrm{H}_{2} \mathrm{~S}$. Because of this, it has limited value and use. Strip air is not introduced in membrane units nor in the MDEA scrubber [1]. These technologies are likely to be the first to find use of $\mathrm{CO}_{2}$ as a resource. An important note on all $\mathrm{CO}_{2}$ removal technologies is the term "upgrading," often used to describe the removal process. With $\mathrm{CO}_{2}$ removal, it becomes possible to inject the remaining methane to a national gas grid, but in all cases, the $\mathrm{CO}_{2}$-carbon from biomass is wasted, making the name misleading.

As biogas consists primarily of $\mathrm{CH}_{4}$ and $\mathrm{CO}_{2}$ in almost equal amounts, the removal of $\mathrm{CO}_{2}$ will almost double the concentration of contaminants like nitrogen $\left(\mathrm{N}_{2}\right)$ or oxygen $\left(\mathrm{O}_{2}\right)$, as these cannot be effectively removed by any of the technologies. 
Fig. 1 Sketch of a pressurized water scrubbing unit for $\mathrm{CO}_{2}$ removal. From Bauer et al. [1]

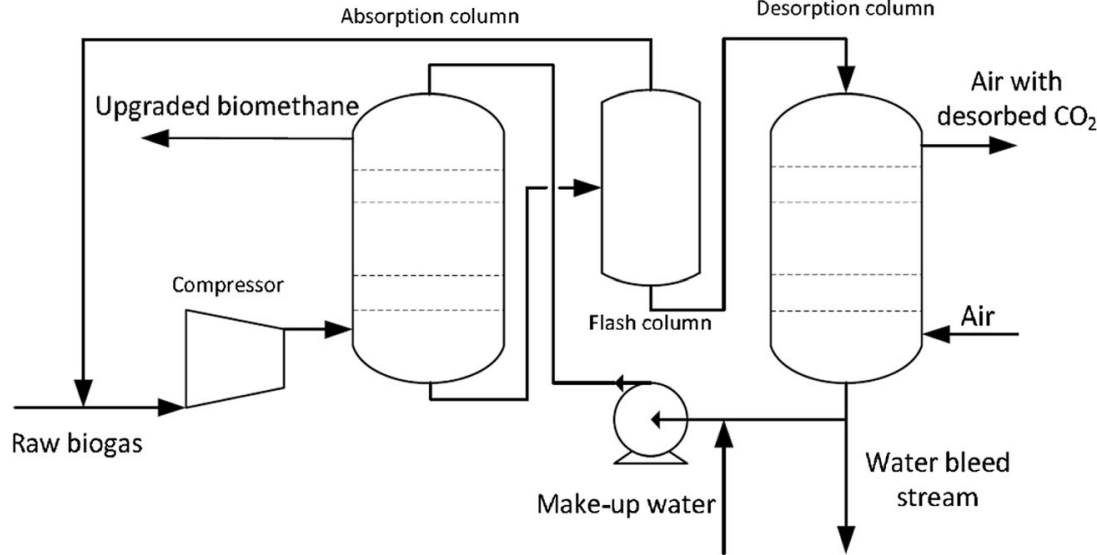

\subsubsection{Removal of $\mathrm{H}_{2} \mathrm{~S}$}

As $\mathrm{H}_{2} \mathrm{~S}$ is corrosive, it is preferably the contaminant removed first. A common large-scale removal option is biological oxidation in a biotrickling filter (BTF), using conditions favoring conversion by Acidithiobacillus thiooxidans [24, 27]. This technique involves oxidation of hydrogen sulfide $\left(\mathrm{H}_{2} \mathrm{~S}_{(\mathrm{g})}\right)$ to sulfur $\left(\mathrm{S}_{(\mathrm{s})}\right)$ or an even higher oxidation state of sulfur (e.g., sulfuric acid, $\mathrm{H}_{2} \mathrm{SO}_{4}$ ). The BTF is robust and requires low maintenance, providing a cheap removal of bulk hydrogen sulfide (from $\sim 1500 \mathrm{ppm}_{\mathrm{V}}$ to $\sim 30 \mathrm{ppm}_{\mathrm{V}}$ levels) $[24,28,29]$. The process of micro-aeration directly in the digester headspace results in the same biological processes. This can be performed if corrosion is not an issue. Typically, this would require a secondary digester. Micro-aeration is a common way to reduce high sulfur levels (from $>3000 \mathrm{ppm}_{\mathrm{V}}$ to $\sim 800 \mathrm{ppm}_{\mathrm{V}}$ levels) [30]. In case further reduction of the hydrogen sulfide level is required, the biological treatment can be combined with a downstream polish using activated carbon (from $\sim 500 \mathrm{ppm}_{\mathrm{V}}$ to $\sim 1 \mathrm{ppm}_{\mathrm{V}}$ levels) (Fig. 2) $[1,2,23,31]$. All technologies typically inject air as the $\mathrm{O}_{2}$ source when operating at industrial scale [24,29]. At sites treating high levels of $\mathrm{H}_{2} \mathrm{~S}\left(>10,000 \mathrm{ppm}_{\mathrm{V}}\right)$, the resulting nitrogen contamination may become a restriction, and the added cost of pure oxygen injection has to be accepted $[29,30,32]$.

The biochemical mechanisms used by $A$. thiooxidans when oxidizing reduced sulfur components are still being identified [33], but results indicate several pathways that may run independent of each other. Oxidizing $\mathrm{H}_{2} \mathrm{~S}$ to sulfur will provide energy (Eq. 4), but if a pathway from sulfur to sulfuric acid is appended, clearly more energy is made available to
A. thiooxidans (Eq. 5) [33-35]. The production of sulfuric acid results in a low $\mathrm{pH}$ of $1-2$, and this environment is intolerable to most other organisms [29].

$\mathrm{H}_{2} \mathrm{~S}_{(\mathrm{aq})} \rightleftarrows \mathrm{H}_{(\mathrm{aq})}^{+}+\mathrm{HS}_{(\mathrm{aq})}^{-} \quad \mathrm{pK}_{\mathrm{a}}=6.9$

$\mathrm{HS}_{(\mathrm{aq})}^{-}+0.5 \mathrm{O}_{2(\mathrm{aq})} \rightleftarrows \mathrm{S}_{(\mathrm{aq})}+\mathrm{OH}_{(\mathrm{aq})}^{-} \quad \Delta \mathrm{G}^{\circ \prime}=-209.4 \frac{\mathrm{kJ}}{\mathrm{mol}}$

$\mathrm{S}_{(\text {aq })}+1.5 \mathrm{O}_{2(\text { aq) }}+\mathrm{H}_{2} \mathrm{O}_{(\mathrm{l})} \rightleftarrows \mathrm{SO}_{4(\text { aq) }}^{2-}+2 \mathrm{H}_{(\text {aq) }}^{+} \quad \Delta \mathrm{G}^{\mathrm{o}^{\prime}}=-796.5 \frac{\mathrm{kJ}}{\mathrm{mol}}$

After the bulk removal in the BTF, the remaining $\mathrm{H}_{2} \mathrm{~S}$ can be removed by adsorption to activated carbon. The technology is fully proven; active carbon is cheap and has a high capacity [36-38]. At some biogas facilities, activated carbon may be the only removal technique installed to reduce investment cost and minimize air contamination [2]. Active carbon has a limited physical adsorption capacity of $\mathrm{H}_{2} \mathrm{~S}$ (Eq. 6), whereas the chemical adsorption of elemental sulfur is very high [37]. Impregnating the carbon with alkali ensures chemical absorption is favored. $\mathrm{H}_{2} \mathrm{~S}$ adsorbs to the carbon where is it oxidized to sulfur (Eq. 7) [37]. Adding a promoter like potassium iodide acts as an oxidation catalyst and at the same time reduces formation of unwanted sulfuric acid [36].

$H_{2} S_{(g)} \rightleftarrows H_{2} S_{(a d s)}$

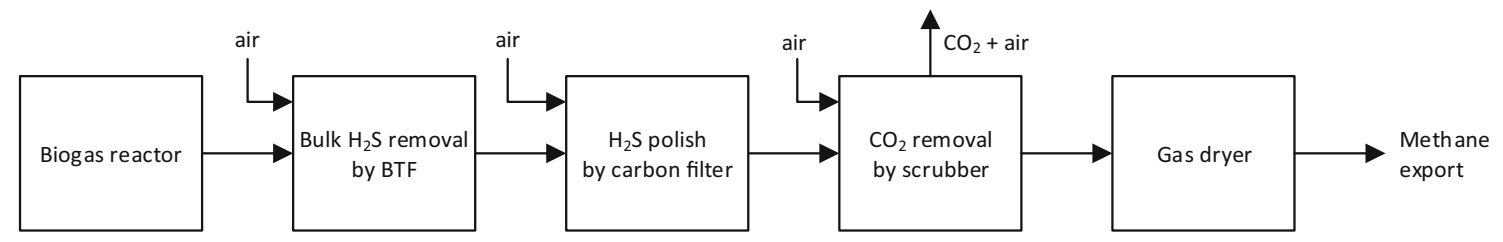

Fig. 2 Typical treatment of biogas before methane export 
$\mathrm{H}_{2} \mathrm{~S}_{(a d s)}+\xi \mathrm{O}_{2(g)} \rightarrow^{\mathrm{H}_{2} \mathrm{O}_{(l)}} \mathrm{S}_{(a d s)}+\mathrm{H}_{2} \mathrm{O}_{(l)}$

The oxidation reaction occurs in a water film at the surface of the carbon particle. Both the biogas reactor and the BTF will saturate the biogas with water, ensuring the moisture requirement by the impregnated carbon filter is always present (typically $>10 \% \mathrm{RH}$ is required [39]). For this reason, a gas dryer should not be installed before a carbon filter when the purpose is $\mathrm{H}_{2} \mathrm{~S}$ removal [38].

Both the biological process and the impregnated activated carbon will require $\mathrm{O}_{2}$ (Eqs. 4, 5, and 7) for the sulfur oxidation reaction $[33,35,37]$. The cheapest $\mathrm{O}_{2}$ source is air, and injecting air both in the BTF and carbon filter is a common practice $[24,38]$. As a result of $\mathrm{H}_{2} \mathrm{~S}$ removal by the $\mathrm{BTF}$ and carbon filter, new contaminants, $\mathrm{N}_{2}$ and $\mathrm{O}_{2}$, are introduced $[23,30,40]$. As $N_{2}$ is nonflammable, it is undesired in the final methane, and air injection is normally kept at a minimum. Addition of $\mathrm{O}_{2}$ at only the stoichiometric requirement would in principle ensure complete conversion of $\mathrm{O}_{2}$ and minimal $\mathrm{N}_{2}$ contamination, but in all practical applications, a surplus of $\mathrm{O}_{2}$ is required to ensure sufficient driving force and to avoid equilibrium restrictions [28-30]. Providing $\mathrm{O}_{2-}$ enriched air or pure $\mathrm{O}_{2}$ will indeed improve the conversion of $\mathrm{H}_{2} \mathrm{~S}$, but due to the cost of pure $\mathrm{O}_{2}$, this addition is only done at sites where the nitrogen contamination cannot be accepted $[29,30,32]$. One recent cost study finds the use of highly enriched air as the most cost-effective solution when the initial sulfur level is $2300 \mathrm{ppm}_{\mathrm{W}}$ [32]. In case of $\mathrm{O}_{2}$ contamination from the $\mathrm{H}_{2} \mathrm{~S}$ cleaning step, this remains a significant issue as potential incorrect dosing of air/oxygen provides a safety concern. Residual oxygen also restricts export options. Different acceptable levels of residual oxygen are the only reason natural gas from Denmark cannot be exported to Germany. The presence of $\mathrm{H}_{2}$ and $\mathrm{O}_{2}$ in the downstream catalytic methanation reactor will effectively produce water. This removes all concerns of residual oxygen in the final gas.

\subsubsection{Requirements for the catalytic methanation reactor}

The performance of a fixed bed methanation reactor loaded with a nickel catalyst $\left(\mathrm{Ni} / \mathrm{Al}_{2} \mathrm{O}_{3}\right)$ has been proven as a reliable technology for pure $\mathrm{CO}_{2}$ methanation $[8,10,17,41,42]$. When upgrading $\mathrm{CO}_{2}$ directly in biogas, the main differences in the reactor design are $[9,21,43-45]$ :

- Heat management of the highly exothermal reaction is easier as the high methane content acts as a heat sink.

- The methane already present in biogas will affect the equilibrium reaction and restrict the conversion of $\mathrm{CO}_{2}$.

The methanation catalyst is very sensitive to sulfur poisoning. Extensive analysis in the chemisorption of sulfur on $\mathrm{Ni} /$ $\mathrm{Al}_{3} \mathrm{O}_{2}$ and similar catalysts has made this one of the most studied catalyst poisonings [22]. Multiple older references recommend a sulfur level in the range of $100 \mathrm{ppb}_{\mathrm{V}}$ for efficient operation of methanation catalyst [46-48]. Newer guidelines note significant catalyst site coverage at levels as low as $1-$ $10 \mathrm{ppb}_{\mathrm{V}}$ [22]. Detecting sulfur at this level represents a significant analytical challenge only recently available to researchers [49]. Since chemisorption of sulfur is a reversible process, several guidelines on catalyst regeneration are available $[50,51]$. The chemisorption process is exothermal and is well described by a Temkin isotherm [52]. A nickel catalyst fully deactivated by $100 \mathrm{ppm}_{\mathrm{V}} \mathrm{H}_{2} \mathrm{~S}$ at $700{ }^{\circ} \mathrm{C}$ was shown to "only" deactivate by $70 \%$ at $800{ }^{\circ} \mathrm{C}$ still in the presence of $100 \mathrm{ppm}_{\mathrm{V}} \mathrm{H}_{2} \mathrm{~S}$. This temperature however promotes catalyst damage by sintering [10]. Operating the $\mathrm{CO}_{2}$ methanation reactor at a temperature around $300{ }^{\circ} \mathrm{C}$, as recommended in earlier work [9], would essentially make the chemisorption of $\mathrm{H}_{2} \mathrm{~S}$ irreversible [22]. An alternative catalyst regeneration method is steam oxidation at around $650{ }^{\circ} \mathrm{C}$. This has been demonstrated as an effective way to remove chemisorbed $\mathrm{H}_{2} \mathrm{~S}$ from nickel $[50,51]$. Although $\mathrm{H}_{2} \mathrm{~S}$ is the dominant sulfur compound in biogas, several other sulfur compounds like $\mathrm{COS}$, DMS, $\mathrm{CS}_{2}$, and thiophene also contribute to sulfur poisoning of $\mathrm{Ni} / \mathrm{Al}_{3} \mathrm{O}_{2}$ catalysts [53-56]. The study by Czekaj et al. [54] finds COS to bind strongly to the catalyst support rather than nickel. As the catalyst is reactivated, the COS is not as effectively removed. Results suggests COS is responsible for re-poisoning of nickel when methanation is resumed. As such, it is crucial to remove all sulfur species in the feed gas, not just $\mathrm{H}_{2} \mathrm{~S}$. A very effective sulfur adsorbent will be required to reach $\mathrm{ppb}_{\mathrm{V}}$ levels of all sulfur contaminants. Current biogas treatment solutions using activated carbon as the final step reduce the $\mathrm{H}_{2} \mathrm{~S}$ level down to 1-2 $\mathrm{ppm}_{\mathrm{V}}$ [23]. Frequent replacement could make this solution reach a lower $\mathrm{H}_{2} \mathrm{~S}$ level, but organic sulfur species cannot be expected to be effectively removed [38]. Deep sulfur removal at biogas sites is a proven challenge [57], and no general guidelines are currently available [38].

\subsection{Aim of this study}

Future power-to-methane systems will rely on direct catalytic methanation of biogas. With a pure $\mathrm{O}_{2}$ stream available from the on-site electrolyzer, it is possible to replace air injection to the BTF and carbon filter, thereby eliminating the $\mathrm{N}_{2}$ contamination. The proposed integration is shown in Fig. 3.

The performance of these technologies when operated on pure oxygen was investigated. A study on the deep sulfur removal limitations of impregnated activated carbon was evaluated as well. The following studies were performed:

- The minimum oxygen requirement was determined for a bench-scale biotrickling filter operated on raw biogas. The 


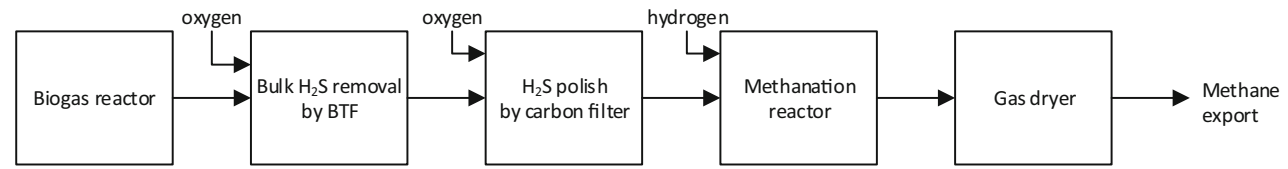

Fig. 3 Proposed integrated treatment of biogas before methanation and export. Hydrogen and oxygen are provided by electrolysis

biotrickling filter was tested both with air injection and pure oxygen injection.

- Removal of sulfur contaminants was tested using a carbon filter operated on raw biogas. The filter was tested both with air injection and pure oxygen injection.

- Biogas treated by the carbon filter was analyzed with regard to hydrogen sulfide and other sulfur compounds at $\mathrm{ppb}_{\mathrm{V}}$ levels.

- Biogas treated by the carbon filter was analyzed with regard to nitrogen and oxygen in the $\mathrm{ppm}_{\mathrm{V}}$ range.

The results from these tests provide the much needed hard data to clarify on the potential benefits of pure oxygen injection as well as the need for a pre-reactor/sulfur guard in the final design.

\section{Material and methods}

In the following experiments, raw biogas was provided from the main biogas reactor at Aarhus University Foulum. Thermophilic digestion was performed with a temperature set point of $51^{\circ} \mathrm{C}$. Average retention time was 15 days. The biomass consisted of cow manure (approx. $60 \mathrm{t} / \mathrm{d}$ ) mixed with plant-based materials (approx. $20 \mathrm{t} / \mathrm{d}$ ) to achieve 14\% dry matter in the feed. Plant-based material was a mixture of livestock bedding, extruded straw, meadow hay, and silage. The total gas production from the main reactor was approx. $150 \mathrm{Nm}^{3} / \mathrm{d}$. The biogas was provided raw, i.e., before downstream sulfur removal using a biotrickling filter and before drying.

\subsection{Bench-scale biotrickling filter}

Basic system parameters of the bench-scale BTF were obtained from the full-scale BTF. This provided a ratio $\mathrm{H} / \mathrm{D}=3$ of the filter medium and a reactor residence time of 1 minute. The bench-scale BTF was constructed from PVC pipe (plastic fittings, silicone tubing, no metal parts). The pipe had a diameter of $11 \mathrm{~cm}$, a height of $116 \mathrm{~cm}$, and allowed treatment of $165 \mathrm{NL} / \mathrm{h}$ biogas. A gas dispersion layer of lightweight expanded clay aggregate (Leca ${ }^{\circledR} \varnothing 10-20 \mathrm{~mm}$ ) was placed before the filter medium (Fig. 4). The filter medium consisted of Leca with immobilized $A$. thiooxidans. The filter medium was kindly donated from a full-scale BTF in operation at Madsen Bioenergi I/S, Spøttrup, Denmark, ensuring a healthy biofilm had already been established ( $\mathrm{pH} 1.5)$. The filter medium was kept wet by purging water and nutrients (Rabasol Chemie, NPK 886, diluted 1:100) at a flow of $30 \mathrm{~mL} / \mathrm{h}$. The reactor was wrapped with a heating mat and kept at $28{ }^{\circ} \mathrm{C}$. Small pumps delivered the flow of biogas and air. A constant gas flow was verified daily by flowmeter (Flonidan, SciFlo G46SOT). The $\mathrm{O}_{2}$ and $\mathrm{H}_{2} \mathrm{~S}$ levels in the biogas were measured two times a day using a portable analyzer (Messtechnik EHEIM GmbH, VISIT 03). The $\mathrm{H}_{2} \mathrm{~S}$ content was in the range of 800-1200 $\mathrm{ppm}_{\mathrm{V}}$ in the period of testing (2 months). Oxygen was provided in cylinders by Air Liquide $\left(\mathrm{O}_{2}\right.$, 99.995\%). The BTFs were operated for 3 days with no changes. After this stabilizing period, changes with air injection and injection of pure $\mathrm{O}_{2}$ were made every second day (Mon, Wed, Fri). Oxygen injection was varied in the range $0.5-5 \%$. Conversion of $\mathrm{H}_{2} \mathrm{~S}$ was calculated from a simple input/ output comparison.

\subsection{Carbon filter}

Removal of $\mathrm{H}_{2} \mathrm{~S}$ and other sulfur compounds to $\mathrm{ppb}_{\mathrm{V}}$ level was accomplished by impregnated alkaline activated carbon. The carbon filter was designed by Haldor Topsøe A/S, Kgs. Lyngby, Denmark, and constructed by Zeton B.V., Enschede, the Netherlands. The filter has an inner diameter of $26.5 \mathrm{~cm}$ and a height of $1.8 \mathrm{~m}$. The filter has a carbon bed height of $1.4 \mathrm{~m}$ and allows treatment of $10 \mathrm{Nm}^{3} / \mathrm{h}$ biogas (Fig. 5). The filter is kept at $50{ }^{\circ} \mathrm{C}$ by electrical tracing. The impregnated

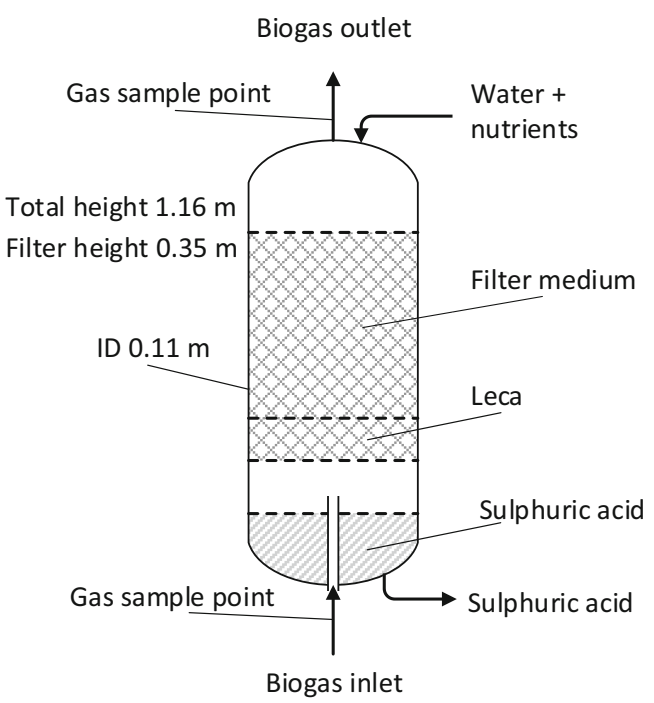

Fig. 4 Bench-scale biotrickling filter used for bulk $\mathrm{H}_{2} \mathrm{~S}$ removal. Treatment of $165 \mathrm{NL} / \mathrm{h}$ raw biogas. The filter was wrapped with a heating mat (not shown) at $28{ }^{\circ} \mathrm{C}$ 


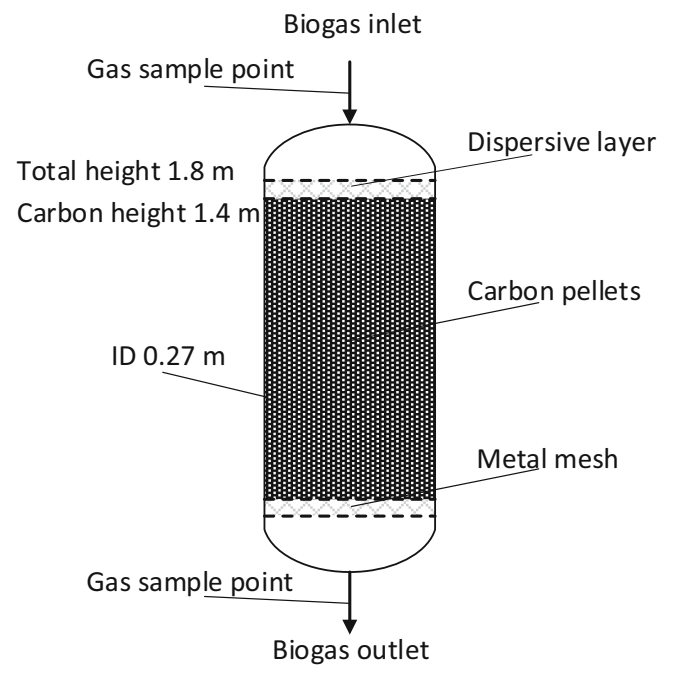

Fig. 5 Carbon filter used for the removal of $\mathrm{H}_{2} \mathrm{~S}$. Treatment of $10 \mathrm{Nm}^{3} / \mathrm{h}$ raw biogas. The filter was heated to $50{ }^{\circ} \mathrm{C}$ using electric tracing

alkaline activated carbon used was SOLCARB® KS3 from Chemviron Carbon, Lancashire, United Kingdom. Pellet diameter is $3 \mathrm{~mm}$ with a typical length of $7 \mathrm{~mm}$ [39]. This product is specifically designed for removal of sulfur compounds in biogas. For optimal removal of $\mathrm{H}_{2} \mathrm{~S}$, an $\mathrm{O}_{2} / \mathrm{H}_{2} \mathrm{~S}$ stoichiometric ratio of 1.8 is recommended [39]. A CEM unit (Bronkhorst, W-202A) controls dosing of air or $\mathrm{O}_{2}$. The concentration of $\mathrm{O}_{2}, \mathrm{~N}_{2}$, and $\mathrm{H}_{2} \mathrm{~S}$ in the biogas was measured in the $\mathrm{ppm}_{\mathrm{V}}$ range using a dual channel (MS5 $\AA$ and PPQ) GC equipped with a thermal conductivity detector. The GC setup and analysis were performed by accredited external lab (Dansk Gasteknisk Center, DGC), using their equipment onsite allowed online analysis. The $\mathrm{H}_{2} \mathrm{~S}$ content was in the range of $850-900 \mathrm{ppm}_{\mathrm{V}}$ in the 4-hour period of the analysis. The filter had been processing $3500 \mathrm{Nm}^{3}$ of biogas at the time of the analysis. Assuming an average $\mathrm{H}_{2} \mathrm{~S}$ level of $1000 \mathrm{ppm}_{\mathrm{V}}$, the carbon filter would have increased $9 \%$ in mass by sulfur adsorption at this point. Oxygen was provided in cylinders by AGA $\left(\mathrm{O}_{2}, 99.995 \%\right)$. Through a valve setup, the GC was sampling from the filter inlet or outlet. Continued measurements were recorded over a period of approx. 1 hour for each test. Due to this setup, analysis of input and output could not be done simultaneously. The center ten data points of each interval was used in the statistical analysis. A paired Student's $t$ test was performed with the software Minitab.

\subsection{Analysis of $\mathrm{H}_{2} \mathrm{~S}$ and other sulfur compounds at $\mathrm{ppb}_{\mathrm{v}}$ level}

Analysis of $\mathrm{H}_{2} \mathrm{~S}$ and other sulfur compounds at ppb level was performed on triplicate samples taken after the carbon filter. The analysis was performed by GC analysis (Agilent Technologies, Gas Chromatograph System 7890A with dual plasma controller, 355 sulfur chemiluminescence detector,
J\&W DB-1 $60 \mathrm{~m}$ column ID $0.52 \mathrm{~mm} 5 \mu \mathrm{m}$ film). The GC method is described in the publication by Liu [49]. To protect the detector from high concentrations of $\mathrm{H}_{2} \mathrm{~S}$, the sample $\mathrm{H}_{2} \mathrm{~S}$ level was confirmed to be below $5 \mathrm{ppm}_{\mathrm{V}} \mathrm{H}_{2} \mathrm{~S}$ by Kitagawa Tubes (Komyo Rikagaku Kogyo K.K., 0.75-37.5 ppm $\mathrm{V}$ ). The $\mathrm{H}_{2} \mathrm{~S}$ content was in the range of $800-1500 \mathrm{ppm}_{\mathrm{V}}$ in the period of testing (45 days). Gas sample bags from Tedlar PVDF (SKC Ltd., Dorset, United Kingdom) were used to bring gas samples to the GC. The bags were analyzed within hours of sampling and were not reused. Samples were obtained straight after loading of carbon material to evaluate the performance of virgin activated carbon. The next set of samples was obtained after treatment of $4000 \mathrm{Nm}^{3}$ of biogas. The last set of samples were obtained after treatment of $8000 \mathrm{Nm}^{3}$ biogas. Assuming an average $\mathrm{H}_{2} \mathrm{~S}$ level of $1000 \mathrm{ppm}_{\mathrm{V}}$ during the test period, the carbon filter would have increased $20 \%$ in mass by sulfur adsorption at this point. This limit was chosen based on an earlier adsorbent comparison study at Aarhus University Foulum, showing a significant breakthrough at an adsorbent weight increase between 15 and 24\% [58].

\section{Results}

Data from three separate experiments are presented.

- Removal of $\mathrm{H}_{2} \mathrm{~S}$ from raw biogas using a biotrickling filter

- Removal of $\mathrm{H}_{2} \mathrm{~S}$ from raw biogas using a carbon filter

- Analysis of sulfur compounds at $\mathrm{ppb}_{\mathrm{V}}$ levels at the outlet of the carbon filter

\subsection{Biotrickling filter}

Results from a bench-scale biotrickling filter loaded with immobilized A. thiooxidans are shown in Fig. 6. Oxygen in the range 0.5 to $5.0 \%$ was provided from a source of air or

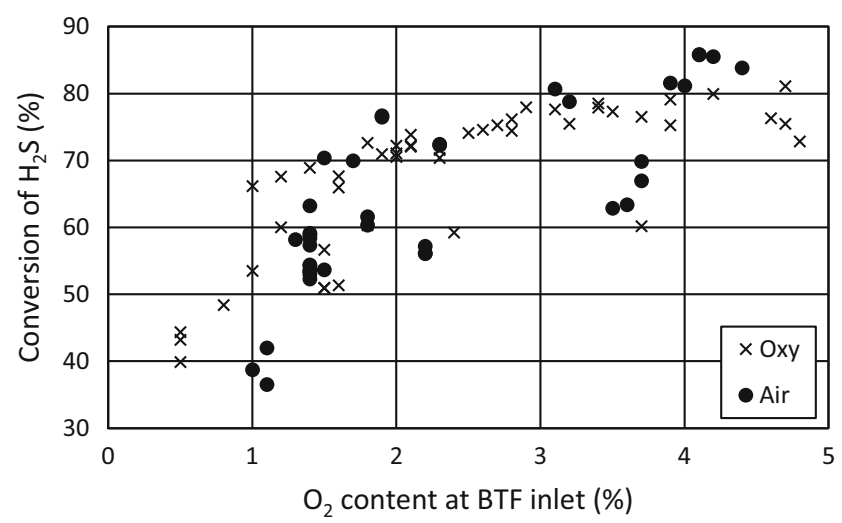

Fig. 6 Conversion of $\mathrm{H}_{2} \mathrm{~S}$ using a bench-scale BTF. Oxygen was provided by air injection or by pure oxygen 
pure oxygen. In the case of air, the results show a conversion drop as the oxygen level reaches $1.0 \%$. Operating with pure oxygen injection the BTF may be able to operate at lower $\mathrm{O}_{2}$ surplus. However, the data contains a lot of scatter, making it difficult to clearly confirm this possibility. To obtain a reasonable conversion, an oxygen content of $2.0 \%$ is required.

\subsection{Carbon filter}

The performance of the carbon filter was evaluated by GC analysis during a continuous run of four cases (Table 1). The oxygen source was changed from air to pure oxygen between case 2 and case 3 .

The results in Fig. 7 show successful removal of $\mathrm{H}_{2} \mathrm{~S}$ from the raw biogas by the carbon filter. Both air and pure oxygen result in efficient removal of $\mathrm{H}_{2} \mathrm{~S}$, but in the case of air injection, a significant contamination of nitrogen is measured. Statistical analysis of the data, Table 2, shows no change in nitrogen concentration between inlet and outlet, as the $p$ value is above 0.05 (it is inert). Injecting pure oxygen reduces the nitrogen contamination to an insignificant level of $400 \mathrm{ppm}_{\mathrm{V}}$.

\subsection{Analysis of hydrogen sulfide and other sulfur components}

A chemiluminescence detector allows detection of sulfur species at $\mathrm{ppb}_{\mathrm{V}}$ level. The analysis (Fig. 8) reveals breakthrough of $\mathrm{CS}_{2}$ even when using newly loaded carbon $\left(0 \mathrm{Nm}^{3}\right.$ biogas processed). The initial breakthrough level of $\mathrm{CS}_{2}$ is however below $10 \mathrm{ppb}_{\mathrm{V}}$. After processing of $4000 \mathrm{Nm}^{3}$ raw biogas, the total sulfur level is around $100 \mathrm{ppb}_{\mathrm{v}}$. Analysis after processing of $8000 \mathrm{Nm}^{3}$ biogas identifies several sulfur species. Both $\mathrm{CS}_{2}$ and DMS are found above $100 \mathrm{ppb}_{\mathrm{V}} \cdot \mathrm{H}_{2} \mathrm{~S}$ was not found in any of the samples. All results are assembled in Table 3.

\section{Discussion}

The feasibility of using pure $\mathrm{O}_{2}$ in existing biogas treatment solutions was investigated. The $\mathrm{H}_{2} \mathrm{~S}$ removal capability of both the BTF and carbon filter was unaffected when air injection was replaced by pure $\mathrm{O}_{2}$. This result shows how these existing technologies offer efficient bulk sulfur removal and how integration with an electrolyzer removes the current issue with nitrogen contamination. A few topics have been selected for further discussion.

Table 1 The four cases evaluated by online GC analysis

\begin{tabular}{lll}
\hline & Air & Pure oxygen \\
\hline Filter inlet & Case 2 & Case 4 \\
Filter outlet & Case 1 & Case 3 \\
\hline
\end{tabular}

\subsection{Oxygen requirement for hydrogen sulfide removal}

The results clearly show how air injection to the BTF cannot be an option if the biogas is to be upgraded in a downstream methanation reactor. The BTF requires significant $\mathrm{O}_{2}$-surplus (up to $2 \%$ ) before the conversion of $\mathrm{H}_{2} \mathrm{~S}$ reaches $80 \%$. At this $\mathrm{O}_{2}$ level, the nitrogen contamination by air injection would exceed $7 \%$, and the gas would be unsuitable for grid export. This is a problem which was also reported by Diaz et al. [59]. However, the BTF has no problem with pure $\mathrm{O}_{2}$ injection. With inexpensive $\mathrm{O}_{2}$ available on-site from the electrolytic production of hydrogen, indeed the BTF may be a feasible technology for bulk $\mathrm{H}_{2} \mathrm{~S}$ removal.

The carbon filter was able to remove $\mathrm{H}_{2} \mathrm{~S}$ from an average level of $880 \mathrm{ppm}_{\mathrm{V}}$ to $0 \mathrm{ppm}_{\mathrm{V}}$. The recommended stoichiometric $\mathrm{O}_{2}$-surplus of 1.8 would result in an $\mathrm{O}_{2}$ requirement of $790 \mathrm{ppm}_{\mathrm{V}}$. Full conversion of $\mathrm{H}_{2} \mathrm{~S}$ would consume $440 \mathrm{ppm}_{\mathrm{V}} \mathrm{O}_{2}$. From Table 2, an $\mathrm{O}_{2}$ injection level of $\sim 1600 \mathrm{ppm}_{\mathrm{V}}$ is observed both in the case of air injection and in the case of pure $\mathrm{O}_{2}$ injection. This level is above the requirement by a factor 2 and could be reduced. Because of this high level of $\mathrm{O}_{2}$ injection, the observed $\mathrm{N}_{2}$ contamination from air injection of $0.7 \%\left(6800 \mathrm{ppm}_{\mathrm{V}}\right)$ could potentially be reduced to $0.35 \%$. For accurate dosing in the $\mathrm{ppm}_{\mathrm{V}}$ range, an on-site CEM calibration should have been performed. Results in Table 2 show $\mathrm{N}_{2}$ pass through the carbon filter as an inert, whereas the consumption of $\mathrm{O}_{2}$ is $350 \mathrm{ppm}_{\mathrm{V}}$ during air injection and $250 \mathrm{ppm}_{\mathrm{V}}$ when injecting pure $\mathrm{O}_{2}$. The complete oxidation of $\mathrm{H}_{2} \mathrm{~S}$ should require $440 \mathrm{ppm}_{\mathrm{V}} \mathrm{O}_{2}$, indicating a clear imbalance. This could be explained by a buffer effect in the carbon filter. To favor oxidation of $\mathrm{H}_{2} \mathrm{~S}$ and thiols, activated carbon can be impregnated with iodine salt as a catalyst $[36,60]$. The impregnated alkaline-activated carbon used here, SolCarb KS3, is impregnated with $1-10 \%$ potassium iodide according to the material safety datasheet. The different redox states of iodine could provide the observed buffer effect. In addition, a lower initial oxygen requirement could be due to the formation of di- and oligo-sulfides, which will still strongly absorb but require less redox equivalents.

A significant reduction in $\mathrm{N}_{2}$ contamination is observed, when the carbon filter is operated on pure $\mathrm{O}_{2}$ (from $6800 \mathrm{ppm}_{\mathrm{V}}$ to $400 \mathrm{ppm}_{\mathrm{V}}$ ). Complete removal of $\mathrm{H}_{2} \mathrm{~S}$ is observed in both cases, confirming the clear benefit of operating the carbon filter on pure $\mathrm{O}_{2}$. The background level of $\mathrm{N}_{2}$ in the biogas of $0.04 \%\left(400 \mathrm{ppm}_{\mathrm{V}}\right)$ is believed to be introduced with the biomass, either as air pockets trapped in the extruded straw, injected along with the manure, or as air introduced in the manure during mixing.

The electrolyzer provides a source of pure $\mathrm{O}_{2}$ enabling replacement of air both to the BTF and carbon filter. This reduces the nitrogen contamination to an insignificant level. The BTF, in particular, does however require surplus $\mathrm{O}_{2}$, to 
Fig. 7 Analysis of $\mathrm{O}_{2}, \mathrm{~N}_{2}$, and $\mathrm{H}_{2} \mathrm{~S}$ before and after the carbon filter. Oxygen was provided by air injection or by pure oxygen. Due to the GC setup, analysis of input and output could not be done at the same time. At the time of the analysis, the carbon filter would have increased $9 \%$ in mass by sulfur adsorption

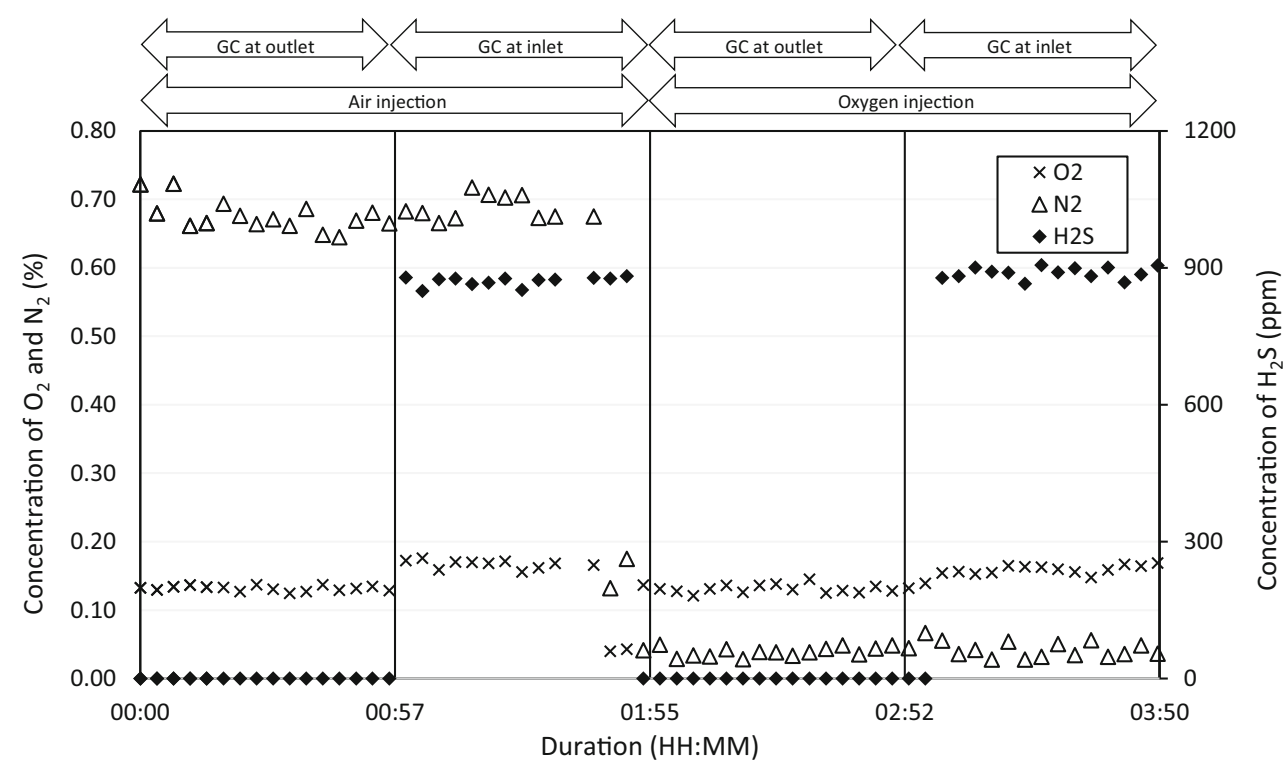

uphold a high conversion of $\mathrm{H}_{2} \mathrm{~S}$. The surplus $\mathrm{O}_{2}$ exiting the BTF removes the need to also inject $\mathrm{O}_{2}$ into the carbon filter. The excess $\mathrm{O}_{2}$, not consumed by the sulfur removal steps, will react with hydrogen to form steam/water. When a sulfur guard is included in the design, a temperature increase from this exothermal reaction will be observed here. If the biogas were to contain $2 \%$ residual $\mathrm{O}_{2}$ from the pretreatment, the additional hydrogen production, to cover both the requirements of the Sabatier reaction and the oxygen removal, would be $2.5 \%$. This would not severely affect plant economics.

\subsection{Performance of the biotrickling filter}

The bench-scale BTF used in the tests was able to remove up to $80 \%$ of the total $\mathrm{H}_{2} \mathrm{~S}$ present in the biogas. This conversion is considerably lower than the reported performance of industrial filters. The BTF filter at the biogas test site at Aarhus University Foulum provides $97 \%$ conversion under stable

Table 2 Data analysis of $\mathrm{H}_{2} \mathrm{~S}, \mathrm{O}_{2}$ and $\mathrm{N}_{2}$

\begin{tabular}{|c|c|c|c|}
\hline \multicolumn{4}{|c|}{ Air injection } \\
\hline & Inlet & Outlet & $\begin{array}{l}\text { Paired t-test } \\
\mathrm{H}_{0}: \mu_{1}=\mu_{2}\end{array}$ \\
\hline $\mathrm{H}_{2} \mathrm{~S}$ & $869 \mathrm{ppm}_{\mathrm{V}} \pm 11 \mathrm{ppm}_{\mathrm{V}}$ & $0 \mathrm{ppm}_{\mathrm{V}} \pm 0 \mathrm{ppm}_{\mathrm{V}}$ & 0.000 \\
\hline $\mathrm{O}_{2}$ & $1665 \mathrm{ppm}_{\mathrm{V}} \pm 62 \mathrm{ppm}_{\mathrm{V}}$ & $1315 \mathrm{ppm}_{\mathrm{V}} \pm 47 \mathrm{ppm}_{\mathrm{V}}$ & 0.000 \\
\hline $\mathrm{N}_{2}$ & $6870 \mathrm{ppm}_{\mathrm{V}} \pm 177 \mathrm{ppm}_{\mathrm{V}}$ & $6723 \mathrm{ppm}_{\mathrm{V}} \pm 221 \mathrm{ppm}_{\mathrm{V}}$ & 0.122 \\
\hline \multicolumn{4}{|c|}{$\mathrm{O}_{2}$ injection } \\
\hline & Inlet & Outlet & $\begin{array}{l}\text { Paired t-test } \\
\mathrm{H}_{0}: \mu_{1}=\mu_{2}\end{array}$ \\
\hline $\mathrm{H}_{2} \mathrm{~S}$ & $891 \mathrm{ppm}_{\mathrm{V}} \pm 12 \mathrm{ppm}_{\mathrm{V}}$ & $0 \mathrm{ppm}_{\mathrm{V}} \pm 0 \mathrm{ppm}_{\mathrm{V}}$ & 0.000 \\
\hline $\mathrm{O}_{2}$ & $1575 \mathrm{ppm}_{\mathrm{V}} \pm 53 \mathrm{ppm}_{\mathrm{V}}$ & $1325 \mathrm{ppm}_{\mathrm{V}} \pm 66 \mathrm{ppm}_{\mathrm{V}}$ & 0.000 \\
\hline $\mathrm{N}_{2}$ & $392 \mathrm{ppm}_{\mathrm{V}} \pm 108 \mathrm{ppm}_{\mathrm{V}}$ & $391 \mathrm{ppm}_{\mathrm{V}} \pm 59 \mathrm{ppm}_{\mathrm{V}}$ & 0.989 \\
\hline
\end{tabular}

process conditions (local measurements not included here). Similar conversion in the range of $90-99 \%$ is also reported in literature [24, 27, 29, 32, 61, 62]. A lower overall conversion of the bench-scale BTF could be partly explained by the feed $\mathrm{O}_{2}$ changes applied every second day during testing, providing little time for $A$. thiooxidans to achieve acclimation [62]. As such, higher conversion would be expected once
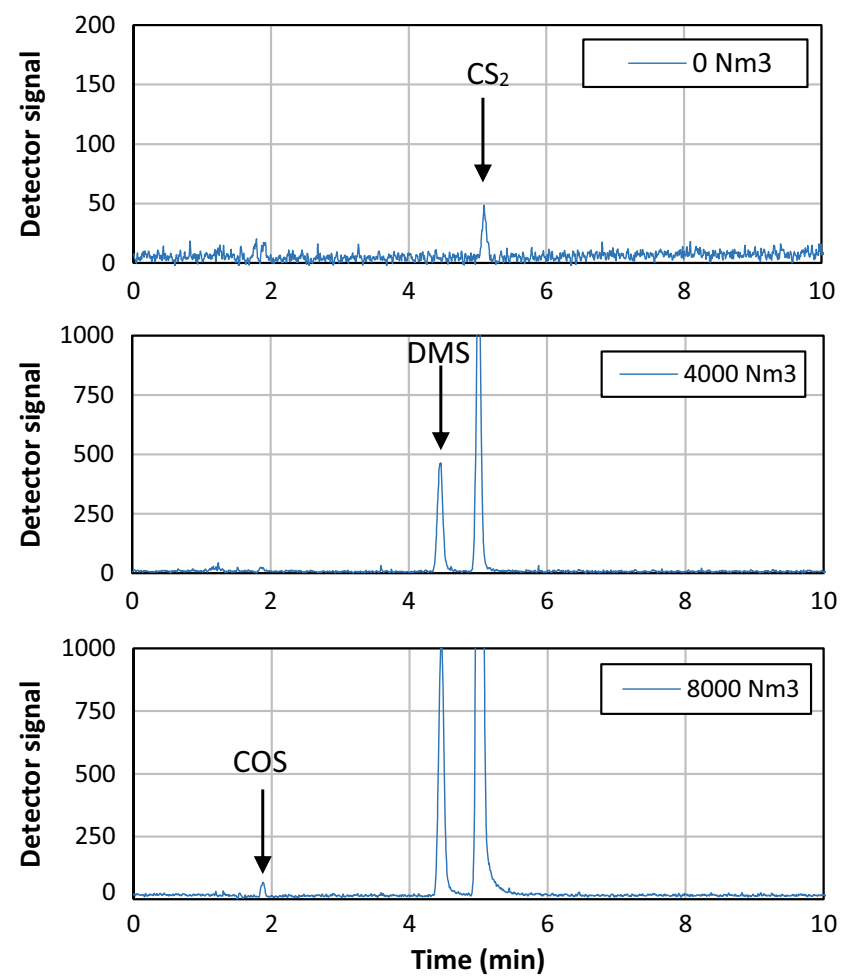

Fig. 8 Analysis of sulfur components after the carbon filter. GC spectrum of virgin carbon $\left(0 \mathrm{Nm}^{3}\right)$, after treatment of $4000 \mathrm{Nm}^{3}$ biogas and after $8000 \mathrm{Nm}^{3}$. Retention times (min): $\mathrm{H}_{2} \mathrm{~S}$ at $1.75, \mathrm{COS}$ at 1.88 , DMS at $4.44, \mathrm{CS}_{2}$ at $5.01 . \mathrm{H}_{2} \mathrm{~S}$ below detection limit in all samples 
Table 3 Analysis of sulfur components in biogas treated by impregnated alkaline-activated carbon. $B D L$ below detection limit

\begin{tabular}{|c|c|c|c|c|c|c|c|c|c|c|c|c|}
\hline \multirow{2}{*}{$\frac{\text { Biogas } \mathrm{Nm}^{3}}{0}$} & \multicolumn{3}{|c|}{$\mathrm{H}_{2} \mathrm{~S} \mathrm{ppb}$ (retention $1.75 \mathrm{~min}$ ) } & \multicolumn{3}{|c|}{$\mathrm{COS} \mathrm{ppb}_{\mathrm{V}}$ (retention $1.88 \mathrm{~min}$ ) } & \multicolumn{3}{|c|}{$\mathrm{DMS} \mathrm{ppb}_{\mathrm{V}}$ (retention $4.45 \mathrm{~min}$ ) } & \multicolumn{3}{|c|}{$\mathrm{CS}_{2} * \mathrm{ppb}_{\mathrm{V}}$ (retention $5.01 \mathrm{~min}$ ) } \\
\hline & BDL & BDL & BDL & BDL & BDL & BDL & BDL & BDL & BDL & BDL & BDL & 2 \\
\hline 4000 & BDL & BDL & $\mathrm{BDL}$ & BDL & BDL & $\mathrm{BDL}$ & 58 & 76 & 93 & 19 & 3 & 28 \\
\hline 8000 & BDL & BDL & BDL & 7 & 14 & 15 & 131 & 117 & 113 & 453 & 408 & 395 \\
\hline
\end{tabular}

*The concentration of $\mathrm{CS}_{2}$ can only be considered as an indication. No $\mathrm{CS}_{2}$ standard was available. The conversion to ppb $\mathrm{V}_{\mathrm{V}}$ is done by assuming a linear response to sulfur by the chemiluminescence detector (using the standard of DMS)

operational conditions have stabilized. A potential problem identified from these tests is an expected reduced conversion in case of stop-and-go operation. With fluctuating prices of electricity from PV and wind farms, stop-and-go operation of the methanation reactor could very well be expected. As desulfurization of biogas is always required, a small $\mathrm{O}_{2}$ storage solution could be implemented, to avoid frequent changes between pure $\mathrm{O}_{2}$ and air injection. This result highlights the need to combine the BTF with a polish step, as insufficient $\mathrm{H}_{2} \mathrm{~S}$ removal could be expected even from day-to-day plant adjustments. The cost associated with the shortened lifetime of carbon will directly couple with the performance of the BTF.

\subsection{Performance of the carbon filter}

The extremely sensitive chemiluminescence detector reveals insights to the performance of the carbon filter. These details are overlooked when performing analysis at $\mathrm{ppm}_{\mathrm{V}}$ scale. $\mathrm{H}_{2} \mathrm{~S}$ is removed with very high efficiency. Even after processing of $8000 \mathrm{Nm}^{3}$ raw biogas results show a $\mathrm{H}_{2} \mathrm{~S}$ concentration well below the detection limit of $1.5 \mathrm{ppb}_{\mathrm{V}}$ (Fig. 8). Assuming an average sulfur concentration of $1000 \mathrm{ppm}_{\mathrm{V}}$ in the raw biogas, this adsorption equals a carbon bed weight increase of $20 \%$ (200 mg sulfur/g carbon). The ability of the filter to retain other sulfur components like dimethylsulfide (DMS), carbon disulfide $\left(\mathrm{CS}_{2}\right)$, and carbonyl sulfide (COS) is clearly not as impressive. After $4000 \mathrm{Nm}^{3}$ of biogas, a leak of DMS and $\mathrm{CS}_{2}$ of $\sim 100 \mathrm{ppb}_{\mathrm{V}}$ is observed. This is above the accepted sulfur level recommended for methanation catalyst [46-48] and clearly specifies the need for a sulfur guard before the methanation reactor. A similar pilot study (COSYMA) also observed DMS as the first sulfur species to break through the carbon adsorbent [56]. As $\mathrm{H}_{2} \mathrm{~S}$ cannot be detected in any of the samples, clearly a continuous analysis of the most predominant sulfur species, $\mathrm{H}_{2} \mathrm{~S}$, is insufficient when evaluating carbon capacity. Often a $\mathrm{H}_{2} \mathrm{~S}$ capacity figure, with a vague breakthrough definition, will be the only benchmark available from different carbon suppliers [38]. This is clearly misleading when evaluating the risk of sulfur breakthrough. From these findings, the most important sulfur contaminant in raw biogas is $\mathrm{CS}_{2}$. The compound is very difficult to retain with active carbon, and the concentration of $\sim 400 \mathrm{ppb}_{\mathrm{V}} \mathrm{CS}_{2}$ (providing
$800 \mathrm{ppb}_{\mathrm{V}}$ sulfur molecules) exceeds recent recommendations of max. $10 \mathrm{ppb}_{\mathrm{V}}$ [22] by almost two orders of magnitude!

A very interesting observation from these findings is that all the sulfur components leaking through the carbon filter (DMS, $\mathrm{CS}_{2}$, and COS) have been reported to be removed from landfill gas and biogas from wastewater treatment facilities by filters like the BTF using A. thiooxidans [63-65]. Potential optimization of the biotrickling filter performance could help in the removal of these organic sulfur compounds.

\subsection{Recommended design}

The integration between a biogas reactor, an electrolyzer, and a reactor for catalytic methanation of biogas could be set up as shown in Fig. 9. Pure $\mathrm{O}_{2}$ is only supplied to the BTF, and a pre-reactor/sulfur guard is included to ensure protection of the methanation catalyst from non- $\mathrm{H}_{2} \mathrm{~S}$ sulfur species.

At the solid oxide electrolyzer plus methanation demonstration unit at Aarhus University Foulum, a sulfur guard using HTZ-51 is included. This absorbent has been demonstrated to work perfectly, as there has been no change in the temperature profile of the methanator even after $1000 \mathrm{~h}$ of operation [66].

\subsection{Contaminants not considered in this study}

This study has focused exclusively on biogas from manure and straw. Although ammonia can be found in this biogas at a level of $\sim 50 \mathrm{ppm}_{\mathrm{V}}$ (local measurements not included here), typical values in biogas are in the range of $10-100 \mathrm{ppm}_{\mathrm{V}}$ [23]. A recent study by Jurgensen et al. [67] on the impact of ammonia on methanation catalysts specifically concludes that the removal is unnecessary. In fact, at a level of $100 \mathrm{ppm}_{\mathrm{V}}$, ammonia showed some benefits like reduced coke formation and a lower deactivation rate on methanation catalysts. The maximum limit of $10 \mathrm{ppm}_{\mathrm{V}}$ ammonia in the final gas (European Norm 16,723:2016) will not be a concern, as ammonia would be subject to cracking in the methanation reactor.

Unlike biogas from farm sites, studies on landfill gas and biogas from wastewater treatment facilities often show significant amounts of siloxanes, halogenated hydrocarbons, and other volatile organic compounds (VOCs). Siloxanes are organic silicon compounds found in products like cosmetics, 


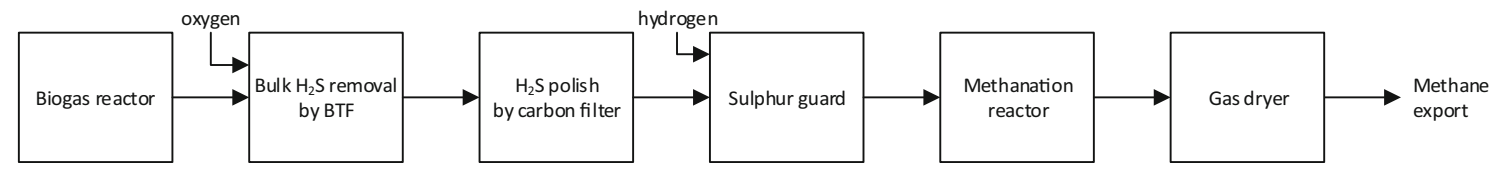

Fig. 9 The recommended setup to allow integration between a biogas reactor, an electrolyzer, and a catalytic methanation reactor. Hydrogen and oxygen are provided by electrolysis

detergents, and pharmaceuticals. Both cyclic and linear siloxanes are found in landfill and biogas [31]. Highest levels are found in biogas from wastewater treatment facilities, and thermophilic digesters seem to struggle with the highest levels [68]. The problem with siloxanes is the formation of inorganic $\mathrm{SiO}_{2}$ deposits inside gas burners causing clogging [69]. A successful removal method is the carbon adsorbent C64 from Airdep installed at the wastewater treatment facility of Collegno, Italy [70]. A second verified option is the carbon adsorbent Bi-On-AC from Bioconservación installed at the Mataró wastewater treatment facility northeast of Barcelona, Spain [31]. Both wastewater treatment facilities convert the produced biogas to electricity using solid oxide fuel cells. As such, this application is extremely sensitive to siloxanes [71].

Landfill gas often contains the highest levels of halogenated hydrocarbons. Possible sources are discarded refrigerants, plastic foams, and paints. Chlorine is the most abundant halogen species. Besides high levels of halogenated hydrocarbons, landfill gas is also the gas containing the highest levels of VOCs $[23,68]$. Both chlorine and VOCs will affect the performance of the methanation catalyst [22]. VOCs are also shown to significantly reduce the capacity of other adsorbents like the adsorbent for siloxanes removal [72]. As landfill gas also contains significant amounts of $\mathrm{N}_{2}$ and $\mathrm{O}_{2}$ from ingress of air, utilizing landfill gas as a $\mathrm{CO}_{2}$ source for catalytic methanation seems less attractive, as custom gas treatment solutions will be required at each site.

\section{Conclusion}

To enable catalytic methanation of $\mathrm{CO}_{2}$ directly in biogas, the performance of a bench-scale biotrickling filter and a carbon filter was evaluated. Current issues with nitrogen contamination from these processes were reduced to insignificant levels, when the filters were operated using pure oxygen. Although hydrogen sulfide was efficiently removed in the carbon filter, analysis at $\mathrm{ppb}_{\mathrm{V}}$ level revealed several sulfur compounds leaking through this last treatment step. These critical sulfur contaminants of raw biogas were found to be carbon disulfide $\left(\mathrm{CS}_{2}\right)$, dimethyl sulfide (DMS), and carbonyl sulfide (COS). A sulfur level at two orders of magnitude above the recommendation for methanation catalyst was found. To avoid issues with sulfur poisoning of the methanation catalyst, a sulfur guard needs to be included in the final design of combined electrolysis-methanation plants.
The technologies selected for treatment of raw biogas are all proven in full scale. The integrated system can be build today serving as a stepping-stone towards a fossil-free future. Solutions utilizing $\mathrm{CO}_{2}$ as a resource have vast potential in current and future energy systems.

Acknowledgments This project was made possible by funding from the Danish Energy Technology Development and Demonstration Program (EUDP) grant 64017-05164.

The authors are grateful for the aid from lab technician Heidi Grønbek Christiansen with regard to $\mathrm{ppb}_{\mathrm{V}}$ analysis of the obtained samples. In addition, special thanks to the student group PBBB consisting of Adisak Manying, Mathias Molbech Christensen, and Jakob Walther Frederiksen for construction, maintenance, and daily monitoring of the biotrickling filters.

\section{Compliance with ethical standards}

Conflict of interest The authors declare that they have no conflict of interest.

Open Access This article is licensed under a Creative Commons Attribution 4.0 International License, which permits use, sharing, adaptation, distribution and reproduction in any medium or format, as long as you give appropriate credit to the original author(s) and the source, provide a link to the Creative Commons licence, and indicate if changes were made. The images or other third party material in this article are included in the article's Creative Commons licence, unless indicated otherwise in a credit line to the material. If material is not included in the article's Creative Commons licence and your intended use is not permitted by statutory regulation or exceeds the permitted use, you will need to obtain permission directly from the copyright holder. To view a copy of this licence, visit http://creativecommons.org/licenses/by/4.0/.

\section{References}

1. Bauer F, Hulteberg C, Persson T, Tamm D (2013) Biogas upgrading - review of commercial technologies. SGC Report. Svensk Gastekniskt Center AB

2. Møller HB, Nielsen KJ (2016) Biogas Taskforce - Udvikling og effektivisering af biogasproduktionen i Danmark. Aarhus Universitet

3. EN16723 Ds (2016) Naturgas og biometan til brug i transport og biometan til injekton i naturgasnettet. Del 1: Sepcifikationer for biometan til injektion i naturgasnettet, vol DS/EN 16723-1:2016. Dansk standard

4. Enerdata (2018) Global Energy Statistical Yearbook 2018

5. Sabatier P, Senderens JB (1902) Nouvelles syntheses du methane. Comptes Rendus Des Séances De L'Académie Des Sciences Section VI - Chimie:514-517

6. Rey MD, Font R, Aracil I (2013) Biogas from MSW landfill: composition and determination of chlorine content with the AOX (adsorbable organically bound halogens) technique. Energy 63:161167. https://doi.org/10.1016/j.energy.2013.09.017 
7. Sudiro M, Bertucco A (2010) Synthetic natural gas (SNG) from coal and biomass: a survey of existing process technologies, open issues and perspectives. In: Potocnik P (ed) natural gas. IntechOpen, https://www.intechopen.com/books/natural-gas/ synthetic-natural-gas-sng-from-coal-and-biomass-a-survey-ofexisting-process-technologies-open-issue, $\mathrm{p} 24$

8. Rönsch S, Schneider J, Matthischke S, Schlüter M, Götz M, Lefebvre J, Prabhakaran P, Bajohr S (2016) Review on methanation - from fundamentals to current projects. Fuel 166:276-296. https:// doi.org/10.1016/j.fuel.2015.10.111

9. Dannesboe C, Nielsen JB, Johannsen I (2019) Synergies between SOEC and catalytic methanation of $\mathrm{CO} 2$ in biogas: implementation of a novel design concept. in preparation

10. Gao J, Liu Q, Gu F, Liu B, Zhong Z, Su F (2015) Recent advances in methanation catalysts for the production of synthetic natural gas. RSC Adv 5(29):22759-22776. https://doi.org/10.1039/c4ra16114a

11. Eckle S, Anfang H-G, Behm RJ (2011) Reaction intermediates and side products in the mathanation of $\mathrm{CO}$ and $\mathrm{CO} 2$ over supported $\mathrm{Ru}$ catalyst in H2-rich reformate gases. J Phys Chem C 115:1361-1361

12. Karelovic A, Ruiz P (2013) Mechanistic study of low temperature $\mathrm{CO} 2$ methanation over $\mathrm{Rh} / \mathrm{TiO} 2$ catalysts. J Catal 301:141-153. https://doi.org/10.1016/j.jcat.2013.02.009

13. Akamaru S, Shimazaki T, Kubo M, Abe T (2014) Density functional theory analysis of methanation reaction of $\mathrm{CO} 2$ on Ru nanoparticle supported on TiO2 (101). Appl Catal A Gen 470:405-411. https://doi.org/10.1016/j.apcata.2013.11.016

14. Aldana PAU, Ocampo F, Kobl K, Louis B, Thibault-Starzyk F, Daturi M, Bazin P, Thomas S, Roger AC (2013) Catalytic CO2 valorization into $\mathrm{CH} 4$ on Ni-based ceria-zirconia. Reaction mechanism by operando IR spectroscopy. Catal Today 215:201-207. https://doi.org/10.1016/j.cattod.2013.02.019

15. Pan Q, Peng J, Sun T, Wang S, Wang S (2014) Insight into the reaction route of $\mathrm{CO} 2$ methanation: promotion effect of medium basic sites. Catal Commun 45:74-78. https://doi.org/10.1016/j. catcom.2013.10.034

16. Park J-N, McFarland EW (2009) A highly dispersed Pd-mg/SiO2 catalyst active for methanation of CO2. J Catal 266(1):92-97. https://doi.org/10.1016/j.jcat.2009.05.018

17. Ducamp J, Bengaouer A, Baurens P, Fechete I, Turek P, Garin F (2018) Statu quo sur la méthanation du dioxyde de carbone : une revue de la littérature. Comptes Rendus Chimie 21(3-4):427-469. https://doi.org/10.1016/j.crci.2017.07.005

18. Bailera M, Lisbona P, Romeo LM, Espatolero S (2017) Power to gas projects review: lab, pilot and demo plants for storing renewable energy and CO 2. Renew Sust Energ Rev 69:292-312. https://doi. org/10.1016/j.rser.2016.11.130

19. Sapountzi FM, Gracia JM, Weststrate CJ, Fredriksson HOA, Niemantsverdriet JW (2017) Electrocatalysts for the generation of hydrogen, oxygen and synthesis gas. Prog Energy Combust Sci 58: 1-35. https://doi.org/10.1016/j.pecs.2016.09.001

20. Hansen JB, Fock F, Lindboe HH (2013) Biogas Upgrading: By Steam Electrolysis or Co-electrolysis of Biogas and Steam? Solid Oxide Fuel Cells 13 (Sofc-Xiii) 57(1):3089-3097. https://doi.org/ 10.1149/05701.3089ecst

21. Posdziech O, Schwarze K, Brabandt J (2018) Efficient hydrogen production for industry and electricity storage via high-temperature electrolysis. Int J Hydrog Energy. https://doi.org/10.1016/j. ijhydene.2018.05.169

22. Bartholomew CH (2001) Mechanisms of catalyst deactivation. Appl Catal A Gen 2012:17-60

23. Arrhenius K, Johansson U (2012) Characterisation of contaminants in biogas before and after upgrading to vehicle gas. SGC Report, Svensk Gastekniskt Center

24. Ryckebosch E, Drouillon M, Vervaeren H (2011) Techniques for transformation of biogas to biomethane. Biomass Bioenergy 35(5): 1633-1645. https://doi.org/10.1016/j.biombioe.2011.02.033
25. Sheets JP, Shah A (2018) Techno-economic comparison of biogas cleaning for grid injection, compressed natural gas, and biogas-tomethanol conversion technologies. Biofuels Bioprod Biorefin 12(3):412-425. https://doi.org/10.1002/bbb.1848

26. PuregasSolutions (2019) The CApure process. Wärtsilä Gas Solutions. http://www.puregas-solutions.com/technology/capureprocess/. Accessed 04-04-2019 2019

27. Smet E, Lens P, Langenhove HV (1998) Treatment of waste gases contaminated with odorous sulfur compounds. Crit Rev Environ Sci Technol 28(1):89-117. https://doi.org/10.1080/ 10643389891254179

28. Mudliar S, Giri B, Padoley K, Satpute D, Dixit R, Bhatt P, Pandey R, Juwarkar A, Vaidya A (2010) Bioreactors for treatment of VOCs and odours - a review. J Environ Manag 91(5):1039-1054. https:// doi.org/10.1016/j.jenvman.2010.01.006

29. Devinny JS, Deshusses MA, Webster TS (1999) Biofiltration for air pollution control. CRC Press

30. Krayzelova L, Bartacek J, Díaz I, Jeison D, Volcke EIP, Jenicek P (2015) Micro-aeration for hydrogen sulfide removal during anaerobic treatment: a review. Rev Environ Sci Biotechnol 14(4):703725. https://doi.org/10.1007/s11157-015-9386-2

31. de Arespacochaga N, Valderrama C, Mesa C, Bouchy L, Cortina JL (2014) Biogas deep clean-up based on adsorption technologies for solid oxide fuel cell applications. Chem Eng J 255:593-603. https:// doi.org/10.1016/j.cej.2014.06.072

32. Diaz I, Ramos I, Fdz-Polanco M (2015) Economic analysis of micro-aerobic removal of $\mathrm{H} 2 \mathrm{~S}$ from biogas in full-scale sludge digesters. Bioresour Technol 192:280-286. https://doi.org/10. 1016/j.biortech.2015.05.048

33. Yin H, Zhang X, Li X, He Z, Liang Y, Guo X, Hu Q, Xiao Y, Cong J, Ma L, Niu J, Liu X (2014) Whole-genome sequencing reveals novel insights into sulfur oxidation in the extremophile Acidithiobacillus thiooxidans. BMC Microbiol 14(1):179. https:// doi.org/10.1186/1471-2180-14-179

34. Cheng YC, Peng RY, Su JCC, Lo DY (1999) Mechanism and kinetics of elemental sulfur oxidation by Thiobacillus thiooxidans in batch fermenter. Environ Technol 20(9):933-942. https://doi.org/ 10.1080/09593332008616888

35. Muller FH, Bandeiras TM, Urich T, Teixeira M, Gomes CM, Kletzin A (2004) Coupling of the pathway of Sulphur oxidation to dioxygen reduction: characterization of a novel membranebound thiosulphate:quinone oxidoreductase. Mol Microbiol 53(4): 1147-1160. https://doi.org/10.1111/j.1365-2958.2004.04193.x

36. Klein J, Henning K-D (1984) Catalytic oxidation of hydrogen sulphide on activated carbons. Fuel 63(8):1064-1067. https://doi.org/ 10.1016/0016-2361(84)90189-3

37. Yan R, Liang DT, Tsen L, Tay JH (2002) Kinetics and mechanisms of $\mathrm{H} 2 \mathrm{~S}$ adsorption by alkaline activated carbon. Environ Sci Technol 36:4460-4466. https://doi.org/10.1021/es0205840

38. Lanzini A, Madi H, Chiodo V, Papurello D, Maisano S, Santarelli M, Van Herle J (2017) Dealing with fuel contaminants in biogas-fed solid oxide fuel cell (SOFC) and molten carbonate fuel cell (MCFC) plants: degradation of catalytic and electro-catalytic active surfaces and related gas purification methods. Prog Energy Combust Sci 61:150-188. https:// doi.org/10.1016/j.pecs.2017.04.002

39. SOLCARB KS3 datasheet (2013). Calgon Carbon Corporation,

40. Bruun $\mathrm{J}$ (2016) Ilt fra biogas - håndtering og udfordringer. GASenergi, Dansk Gasteknisk Center

41. Wang W, Gong J (2010) Methanation of carbon dioxide: an overview. Front Chem Sci Eng 5(1):2-10. https://doi.org/10.1007/ s11705-010-0528-3

42. Hoekman SK, Broch A, Robbins C, Purcell R (2010) CO2 recycling by reaction with renewably-generated hydrogen. International Journal of Greenhouse Gas Control 4(1):44-50. https://doi.org/10.1016/j.ijggc.2009.09.012 
43. HELMETH (2018) Report on the overall system design and operational tests of the combined system. Deliverable 4:2

44. Gutiérrez-Martín F, Rodríguez-Antón LM (2018) Power-to-SNG technologies by hydrogenation of $\mathrm{CO} 2$ and biomass resources: a comparative chemical engineering process analysis. Int J Hydrog Energy. https://doi.org/10.1016/j.ijhydene.2018.09.168

45. Witte J, Calbry-Muzyka A, Wieseler T, Hottinger P, Biollaz SMA, Schildhauer TJ (2019) Demonstrating direct methanation of real biogas in a fluidised bed reactor. Appl Energy 240:359-371. https://doi.org/10.1016/j.apenergy.2019.01.230

46. Bartholomew CH, Weatherbee GD, Jarvi GA (1979) Sulfur poisoning of nickel methanation catalyst. J Catal 60:257-269

47. Harms H, Höhlein B, Skov A (1980) Methaniserung kohlenmonoxidreicher Gase beim Energi-Transport. Chemie Ingenieur Technik 52(6):504-515

48. Twigg MV (1996) Catalyst handbook. CRC Press

49. Liu W (2008) Detection of sulfur compounds in natural gas according to ASTM D5504 with Agilent's dual plasma sulfur chemiluminescence detector (G6603A) on the 7890A gas chromatograph. Hydrocarbon Processing Agilent Technologies Co. Ltd.

50. Rostrup-Nielsen JR (1971) Some principles relating to the regeneration of sulfur-poisoned nickel catalyst. J Catal 21:171-178

51. Appari S, Janardhanan VM, Bauri R, Jayanti S (2014) Deactivation and regeneration of $\mathrm{Ni}$ catalyst during steam reforming of model biogas: an experimental investigation. Int J Hydrog Energy 39(1): 297-304. https://doi.org/10.1016/j.ijhydene.2013.10.056

52. Alstrup I, Rostrup-Nielsen JR, Røen S (1981) High temperature hydrogen sulfide chemisorption on nickel catalysts. Appl Catal 1(5):303-314. https://doi.org/10.1016/0166-9834(81)80036-X

53. Li TH, Wang CM, Liu XY, Xie XG (2008) DFT study on the gas phase reaction of Ni+ with CS2. Chem Phys Lett 458(1-3):19-23. https://doi.org/10.1016/j.cplett.2008.04.057

54. Czekaj I, Struis R, Wambach J, Biollaz S (2011) Sulphur poisoning of Ni catalysts used in the SNG production from biomass: computational studies. Catal Today 176(1):429-432. https://doi.org/10. 1016/j.cattod.2010.10.078

55. Struis RPWJ, Schildhauer TJ, Czekaj I, Janousch M, Biollaz SMA, Ludwig C (2009) Sulphur poisoning of Ni catalysts in the SNG production from biomass: a TPO/XPS/XAS study. Appl Catal A Gen 362(1-2):121-128. https://doi.org/10.1016/ j.apcata.2009.04.030

56. Calbry-Muzyka AS, Gantenbein A, Schneebeli J, Frei A, Knorpp AJ, Schildhauer TJ, Biollaz SMA (2019) Deep removal of sulfur and trace organic compounds from biogas to protect a catalytic methanation reactor. Chem Eng J 360:577-590. https://doi.org/10. 1016/j.cej.2018.12.012

57. Biollaz S, Calbry-Muzyka A, Schildhauer T, Witte J, Kunz A (2017) Direct Methanation of biogas. Paul Scherrer Institut,

58. På vej mod metansamfundet? (2012) (Roadmap towards the methane society). Agro Business Park, Innovationsnetværket for Biomasse, IMBIOM

59. Diaz I, Lopes AC, Perez SI, Fdz-Polanco M (2010) Performance evaluation of oxygen, air and nitrate for the micro-aerobic removal of hydrogen sulphide in biogas from sludge digestion. Bioresour
Technol 101(20):7724-7730. https://doi.org/10.1016/j.biortech. 2010.04.062

60. Code KR, Provenzano J (2012) Activated carbon associated with iodine. Canada Patent

61. Webster TS, Devinny JS, Torres EM, Basrai SS (1996) Biofiltration of odors, toxics and volatile organic compounds from publicly owned treatment works. Environ Prog 15(3):141-147. https://doi. org/10.1002/ep.670150311

62. de Arespacochaga N, Valderrama C, Mesa C, Bouchy L, Cortina JL (2014) Biogas biological desulphurisation under extremely acidic conditions for energetic valorisation in solid oxide fuel cells. Chem Eng J 255:677-685. https://doi.org/10.1016/j.cej.2014.06.073

63. Smet E, Van Langenhove H, Verstraete W (1996) Long-term stability of a biofilter treating dimethyl sulfide. Appl Microbiol Biotechnol 46:191-196. https://doi.org/10.1007/s002530050804

64. Plas C, Wimmer K, Holubar P, Mattanovich D, Danner H, Jelinek E, Harant H, Braun R (1993) Degradation of carbon disulphide by a Thiobacillus isolate. Appl Microbiol Biotechnol 38(6):820-823. https://doi.org/10.1007/bf00167151

65. Sivelä S, Sundman V (1975) Demonstration of Thiobacillus-type bacteria, which utilize methyl sulphides. Arch Microbiol 103(1): 303-304. https://doi.org/10.1007/bf00436365

66. Dannesboe C, Hansen JB, Johannsen I (2019) Catalytic methanation of $\mathrm{CO} 2$ in biogas: experimental results from a reactor at full scale. Reaction Chemistry \& Engineering. https://doi.org/10.1039/ c9re00351g

67. Jurgensen L, Ehimen EA, Born J, Holm-Nielsen JB, Rooney D (2015) Influence of trace substances on methanation catalysts used in dynamic biogas upgrading. Bioresour Technol 178:319-322. https://doi.org/10.1016/j.biortech.2014.09.080

68. Papadias DD, Ahmed S, Kumar R (2012) Fuel quality issues with biogas energy - an economic analysis for a stationary fuel cell system. Energy 44(1):257-277. https://doi.org/10.1016/j.energy. 2012.06.031

69. de Arespacochaga N, Valderrama C, Raich-Montiu J, Crest M, Mehta S, Cortina JL (2015) Understanding the effects of the origin, occurrence, monitoring, control, fate and removal of siloxanes on the energetic valorization of sewage biogas - a review. Renew Sust Energ Rev 52:366-381. https://doi.org/10.1016/j.rser.2015.07.106

70. Gandiglio M (2018) DEMOSOFC project: results from an industrial-size biogas-fed SOFC. Paper presented at the 4th BIOGAS SCIENCE conference, Torino, Italy, 17-19 September 2018

71. Madi H, Lanzini A, Diethelm S, Papurello D, Van herle J, Lualdi M, Gutzon Larsen J, Santarelli M (2015) Solid oxide fuel cell anode degradation by the effect of siloxanes. J Power Sources 279:460 471. https://doi.org/10.1016/j.jpowsour.2015.01.053

72. Lampe $\mathrm{S}$ (2006) Assessment of fuel gas cleanup systems for waste gas fueled power generation. Electric Power Research Institute

Publisher's Note Springer Nature remains neutral with regard to jurisdictional claims in published maps and institutional affiliations. 